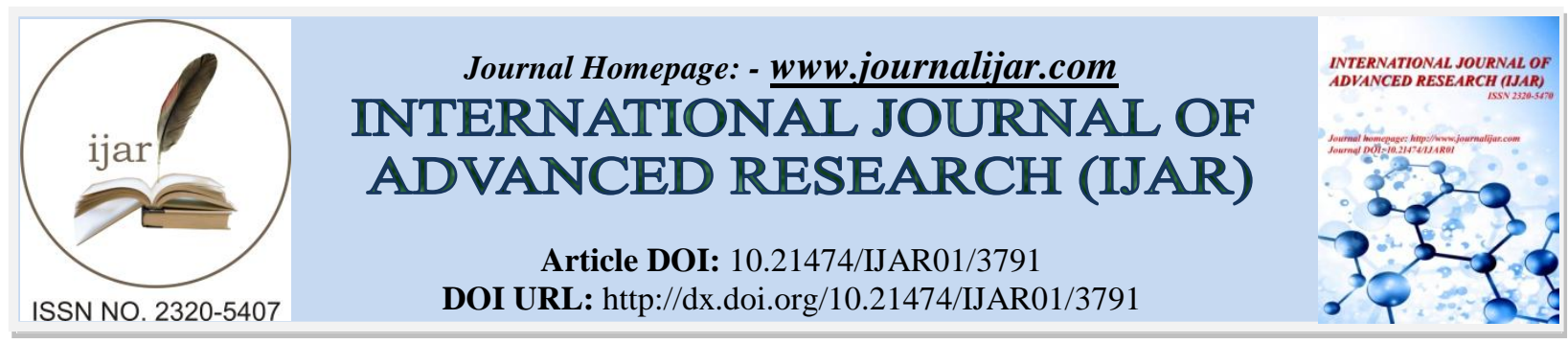

RESEARCH ARTICLE

\title{
BIO-THERAPY OF MOLASSES SPENT WASH USING HYBRID ANAEROBIC BAFFLE REACTOR.
}

\author{
R.Banupriya ${ }^{1}$, G.Reshma ${ }^{2}$, T.Yasika ${ }^{2}$, M. Suguna ${ }^{2}$ and A. Sandhiya ${ }^{2}$ \\ 1. Assistant professor, Department of Civil Engineering, Sethu Institute of Technology,Madurai,India. \\ 2. UG Students, Department of Civil Engineering, Sethu Institute of Technology.
}

\section{Manuscript Info}

Manuscript History

Received: 08 February 2017

Final Accepted: 01 March 2017

Published: April 2017

Key words:-

Molasses spent wash, Green Chemistry Approach, HABR, Biogas, Treated

Water, Bio-manure

\section{Abstract}

The industrialization has not only brought development and prosperity but eventually disturbed the ecosystem. One of the biggest environmental problems faced by the world is management of molasses spent washes released from sugar industry. The impacts is visible in the form of pollution of land and water resources. The conventional methods of treatment are very costly, energy intensive and generate toxic sludge. Even-though, pollution prevention focuses on preventing the generation of waste, waste minimization reduces the volume and toxicity of hazardous waste by adopting proper recycling and reuse methods .Now-a-days the need for waste minimization and obtaining revenue through by-product recovery is an emerging trend in treatment processes. In addition to that, consumption of a large quantity of processed water and safe disposal of enormous volumes of effluent is a major challenge. This research has tried to harness the potential of hybrid anaerobic baffle reactor aided with principles of Green Chemistry Approach to treat molasses spent wash in controlled condition. Also,hybrid technologies having biological processes as a core appears to be more challenging. In our project, molasses spent wash released from sugar industry is treated anaerobically using hybrid anaerobic baffle reactor. With this new hybrid \& biological treatment technology aided with the principle of green chemistry approach,we were able to treat spent wash, utilize by-products like biogas, treated water and organic manure for revenue generation and in agricultural practices respectively thereby reducing the demand for irrigation water, fossil fuels and organic manure for agricultural fields. The aim of this study is to investigate the use of HABR in the reduction of BOD, COD and produce valuable byproducts from molasses spent wash. The study involves the examination of experimental conditions such as $\mathrm{pH}$ of the solution, concentration of the solution, and amount of NPK present in sludge for direct utilization as organic manure.

Copy Right, IJAR, 2017,. All rights reserved.

\section{Introduction:-}

Sugarcane, the raw material for sugar mills, is one of the leading crops of the country. Molasses, a byproduct of sugar industries is the major raw material for distilleries in India. There are about 356 molasses based distilleries and about 110 grain based distilleries in the country. Sugar industry and distilleries are mutually dependent and in a way 
are inseparable. Consequently, agricultural and rural economy mainly depends upon the sugarcane farming and associated industries. Besides, sugar mills, distilleries and associated industries provide large employment potential and contribute substantially to economic development. There is a need of modernization and scientific revolution arises as the tremendous changes occur in the surrounding area of distillery industry and environmental crises problem also terrestrial and aquatic land badly affected due to these industries As per the statistical information. In India there are approximately 319 sugar industries producing alcohol $3.25 \times 109$ liters and generating 40.4. X 109 liters of spent wash annually. Since the sugar industry depends predominantly on sugarcane as a source of feed stock, it is but natural that the ultimate by-product of this industry is cane molasses, which is generated after the sugar is extracted out of the concentrated cane juice as a result of several physicochemical processes. . Despite its commercial importance, the known fact that distilleries are identified and categorized among the most is polluting industries by the Central Pollution Control Board (CPC).This section of the industry is vital for the commercial health of the country as a large population segment throughout the country is dependent on the agricultural produce which goes into this sector as raw material.

In addition to that, consumption of a large quantity of processed water and disposal of enormous volumes of effluent is a major challenge for this sector. The unwanted dark brown coloured residual liquid waste produced from sugar industry is called spent wash. Press mud and Spent Wash are the main waste materials resulting from sugar and distillery industries, respectively. Although the value of press mud as organic manure has been well recognized, disposal of Spent Wash having high COD \& BOD and salt load is still a challenge. Still, disposal of the large volume of raw Spent Wash is a serious concern of the distilleries.

Today modern and large numbers of clean up technologies are explored to reduce pollution load and efficiently treat the molasses spent wash. But the economical and eco-friendly distillery spent treatment is a great challenge to environmentalists. In most cases it has been found that biological processes are more economic and efficient than physical/chemical treatment. In the recent past there have been significant developments in treatment of Spent Wash, including adoption of anaerobic digestion where the Spent Wash is subjected to bio-digestion to produce methane that supplements the energy needs of the distillery as boiler fuel.So,an integrated approach, including the combination of biological treatment processes and Green Chemistry Principles, will help in meeting the effects of effluent disposal, besides achieving higher energy and product efficiencies is a biggest challenge.

Anaerobic treatment technology has proven over recent years to be a better alternative to aerobic processes, especially for the treatment of high strength wastewaters. It could be a cost-effective solution to many challenges facing the industry today: rising energy costs, high sludge disposal costs and tighter effluent limitations. Properly designed anaerobic treatment systems have the potential to provide a renewable energy source (biogas), consume less energy and generate less sludge. The hybrid anaerobic baffled reactor (HABR) is one of the high-rate anaerobic designs developed by McCarty and co-workers at Stanford University.The HABR has been described as a series of USABs which does not require granulation for its operation. Therefore, it has lower start-up period than the other high rate reactors. The HABR uses a series of vertical baffles to force the wastewater to flow under and over them as it passes from inlet to outlet, the wastewater can come into intimate contact with a large amount of active biomass, while the effluent remains relatively free of biological solids. Moreover, the HABR features in separating acidogenesis and methanogens longitudinally down the reactor and enhancing reactor stability.

\section{Problem Formulation:-}

Now a day's wastewater treatment is not an easy task. The distillery wastewater has high amount of organic matter so without treatment pull down in water stream is not ethical. The quantity and the general quality of food processing industries generating wastewater have both economical and environmental consequences with respect to its treatability and disposal methods. The effluent from the sugar industry when disposed without proper treatment causes serious hazard to surrounding land and water bodies because they prevent sunlight penetration into an aquatic system thereby dissolved oxygen concentration is depleted .The molasses spent wash (MSW) is a potential water pollutant in two ways:

- First, the highly colored nature of MSW can block out sunlight from rivers and streams, thus reducing oxygenation of the water by photosynthesis and hence becomes problem to aquatic life.

- Secondly, it has a high pollution load which would result in eutrophication of contaminated water sources.

Also there has been increasing demand for more efficient systems for the treatment of waste water arises.Physicochemical treatment such as adsorption, coagulation, electro coagulation, flocculation, oxidation, 
membrane technology, evaporation and combustion methods are implemented for decolourization and to reduce organic load. These methods are more effective for colour removal as well as reduction in organic loading, but sludge is generated on large scale and another method is required for disposal of sludge.Among various biological treatment process, aerobic treatment helps to reduce the chemical oxygen demand (COD), and Biological oxygen demand up to 50 to $70 \%$, but till $100 \%$ color, COD and BOD are not reduced. So the adoption of anaerobic treatment technology with high rate anaerobic digesters proves to be a better alternative for higher energy and useful by-product with greater efficiency.

In the present study,the combination of anaerobic treatment method and green chemistry principles helps to minimize the generation of hazardous wastes and of large volumes of effluents thereby achieving Zero Discharge Paradigm. The method of anaerobic treatment offers many potential advantage in energy saving, process enhancement and processing time to remove BOD \& COD. In this research, HABR was used as high rate anaerobic digester to assist anaerobic treatment process because of its low cost, availability and its efficiency in producing fruitful byproducts for utilization as energy aswellas supply of water to and in agricultural purposes.

\section{Research Objective:-}

- The main objectives is to examine the prompt start-up and the feasibility of HABR on treatment of molasses spentwash after modification, in terms of evaluation of removal of BOD,COD, variation of PH, TFS,TVS and TFS and biomass analysis of anaerobic granular sludge.

- To ensure safe and proper disposal of the treated effluent.

- To convert effluent into useful byproduct and recover energy.

- To explore the use of anaerobic digestion as complete solution to reduce BOD \& COD.

- To analyze and suggest biologically cost-efficient treatment method for production of useful resources.

- To experimentally investigate the reuse of treated effluents for agriculture and feed stock or as manure.

- To stress the need for "Green chemistry approach" and "zero discharge" paradigm.

- To place a Mirror before the industry in the form of Environmental Performance Rating

Scope:-

- To improve current research by increasing the percentage of BOD \& COD removal from MSW using Hybrid Anaerobic Baffle Reactor.

- To open up opportunities to increase the demand on wastewater treatment by using biologically cost effective treatment technology as proven by researchers that it has a lot of benefits.

- To prevent discharge of waste water into land and water resources which can causes foul odor and toxicity that can be potential hazard to human health and environment.

- To reduce the demand for water resources and fertilizer.

- To explore biogas is an alternative source of energy in spite of fuels.

- Obtaining Revenue from energy sales and to raise the economic growth of the country.

\section{Methodology:-}

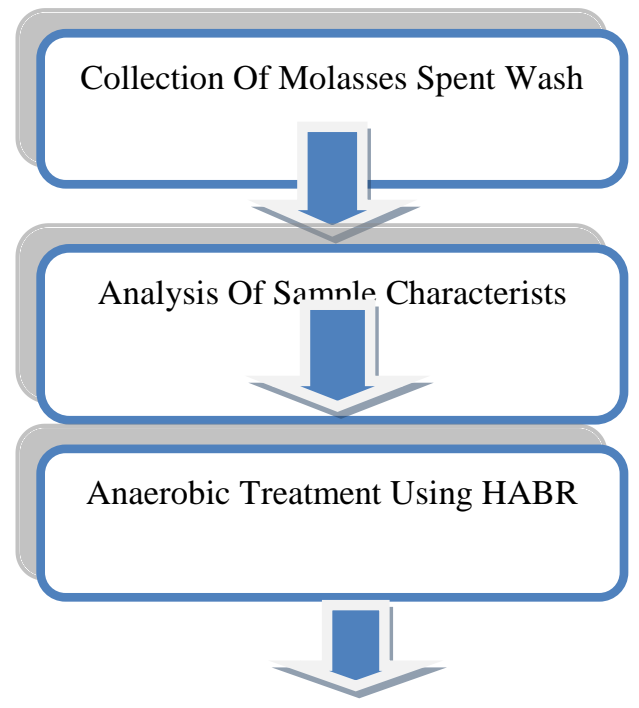




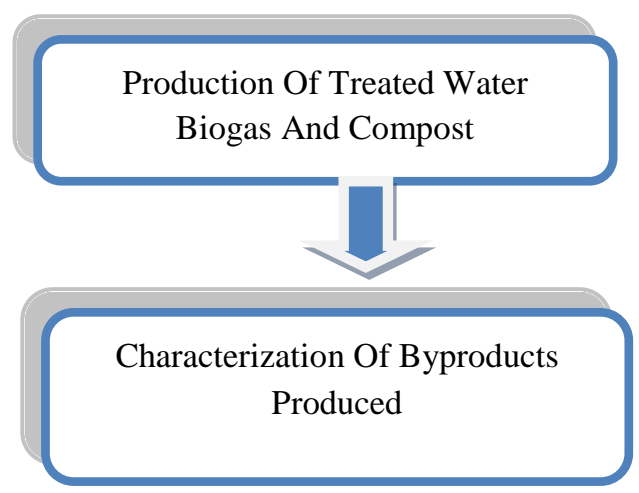

Fig 1:- Flowchart for treatment for molasses spent wash.

\section{Collection Of Sample:-}

- The sample has been collected from National Corporative Sugar Mill, Alanganallur, and Madurai district.The colour of the molasses spent wash appears in dark brown colour with unpleasant burnt sugar odour. The sample is collected and stored in a plastic container and is preserved in refrigerator and sealed to prevent the attack of microbes.

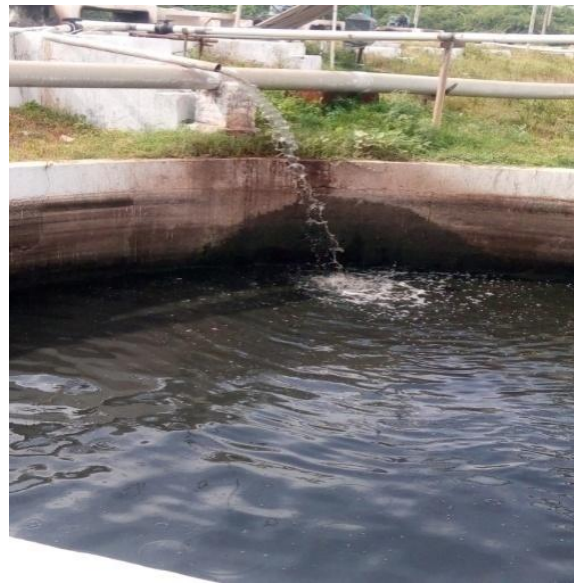

Fig 2:- Dark brown effluent.

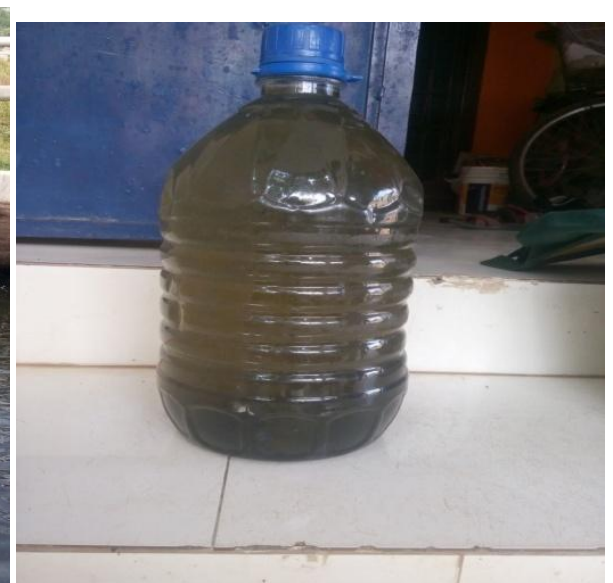

Fig 3:-Storage in plastic container.

\section{Process Description:-}

The anaerobic treatment of molasses spent wash is carried out by using HABR after which the byproducts so produced can be utilized for various domestic, agricultural and commercial purposes. Anaerobic treatment technology has proven over recent years to be a better alternative to aerobic processes, especially for the treatment of high strength wastewaters. It could be a cost-effective solution to many challenges facing the industry today: rising energy costs, high sludge disposal costs and tighter effluent limitations. Properly designed anaerobic treatment systems have the potential to provide a renewable energy source (biogas), consume less energy and generate less sludge.

\section{Anaerobic treatment:-}

Biological process carried out in the absence of oxygen for the stabilization of organic materials by conversion to methane and inorganic end products such as Carbon-dioxide and ammonia.

Organic materials + nutrients

(Anaerobic process)

Methane + carbon dioxide + ammonia + biomass 


\section{Hybrid Anaerobic Baffle Reactor:-}

The hybrid anaerobic baffled reactor (HABR) is one of these high-rate anaerobic designs developed by McCarty and co-workers at Stanford University. Hybrid Type of reactor is a combination of an upflow anaerobic sludge blanket reactor with an anaerobic filter or anaerobic contact process or a combination of two reactorsUASB

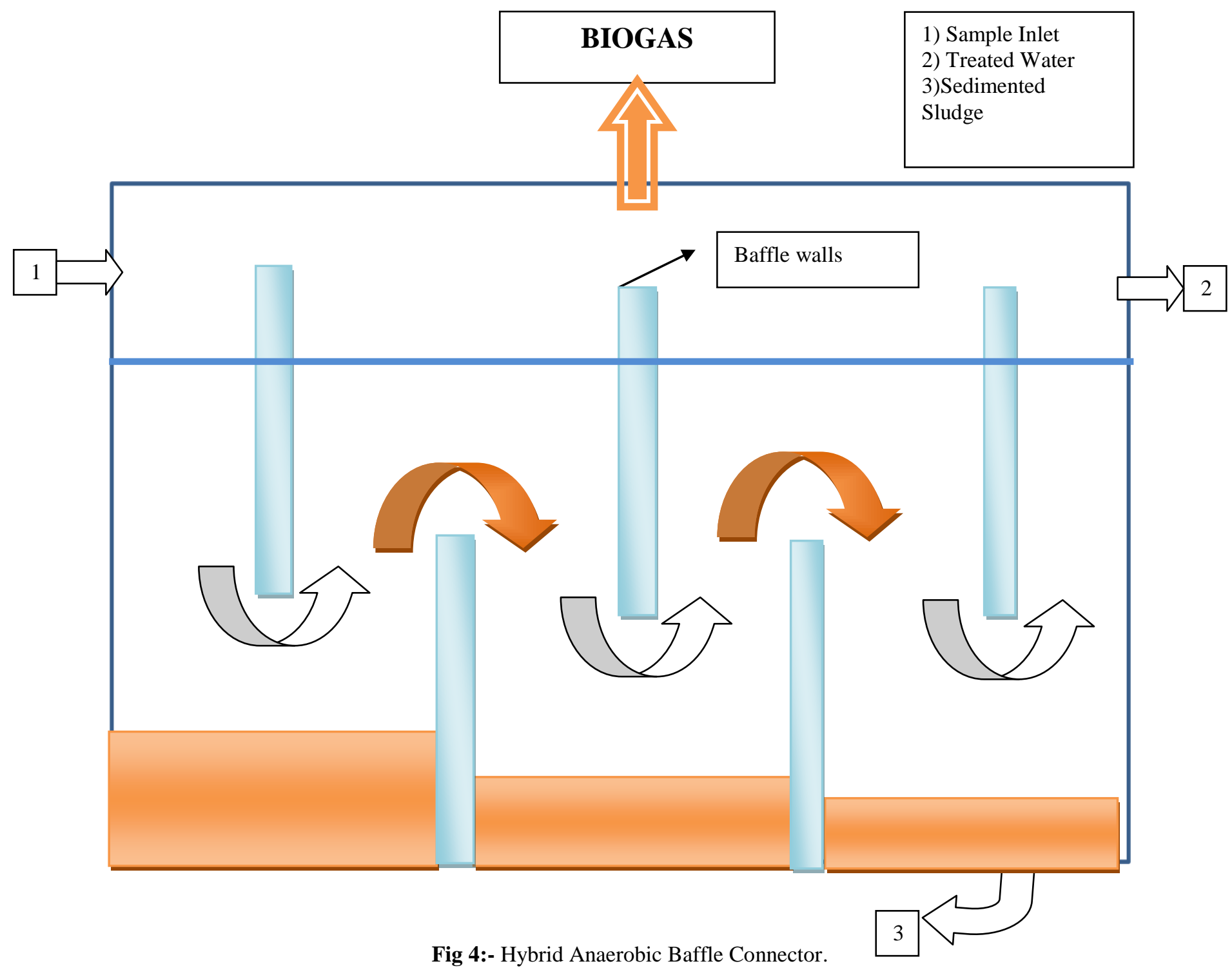

\section{Working Principle:-}

The reactor used for treatment of molasses spent wash is Hybrid Anaerobic Baffle Reactor. The HABR uses a series of vertical baffles to force the wastewater to flow under and over them as it passes from inlet to outlet, the wastewater can come into intimate contact with a large amount of active biomass, while the effluent remains relatively free of biological solids.

Criteria for Carrying Out the Treatment Process in HABR:

- The treatment process should be carried out in the absence of oxygen.

- The ambient room temperature should be between $29-37^{\circ} \mathrm{C}$.

- Temperature around the mesophilic range of $30-38^{\circ} \mathrm{C}$ should be maintained.

- The amount of BOD\& COD in each stage of hybrid anaerobic baffle reactor should be estimated. 
- Implementation of "Green Chemistry Approach" helps to achieve "zero discharge paradigm" thereby producing useful and recyclable byproducts.

\section{Reactor Configuration:-}

- VERTICAL BAFFLE WALLS-helps to enhance solid retention to allow better substrate accessibility to methanoges

- SETTLING CHAMBER-enhances solid retention and prevents wash out of solids \& treatment of high strength wastewater

- GAS CHAMBER-ease and control of gas measurement,provides enhanced reactor stability

- COLLECTION CHAMBER-aids in collection of sludge \&treated water produced during the treatment of molasses spentwash.

\section{Step By Step Procedure In HABR Treatment Process:-}

Step 1:- Firstly, the molasses spent wash diluted with $20 \%$ water is sent into the reactor with anaerobic condition as specified above.

Step 2:- In the first stage of reactor process, the hydrolytic fermentative bacteria hydrolyze the complex polymer substrate like cellulose, fats and proteins to soluble compounds. The formation of acidogenic bacteria helps in the conversion of soluble compounds to organic acids such as carbonic acids, alcohols, sugars, hydrogen, and carbon dioxide. The reactor temperature is maintained at $35^{\circ} \mathrm{C}$.

Step 3:- The process of acetogenesis takes place.Acetogenesis is nothing but conversion of organic acids to acetic acid in the presence of acetogenic bacteria.

Step 4:- At this stage, the reaction gets completed by

1. formation of biogas with high methane content

2. production of treated water within CPCB limits

3. Production of Organic Manure with necessary plant nutrients like NPK.

Step 5:- Biogas so produced in each stage is collected using gas chamber.

Step 6:- Treated water \& sludge remains is collected using collection chamber.

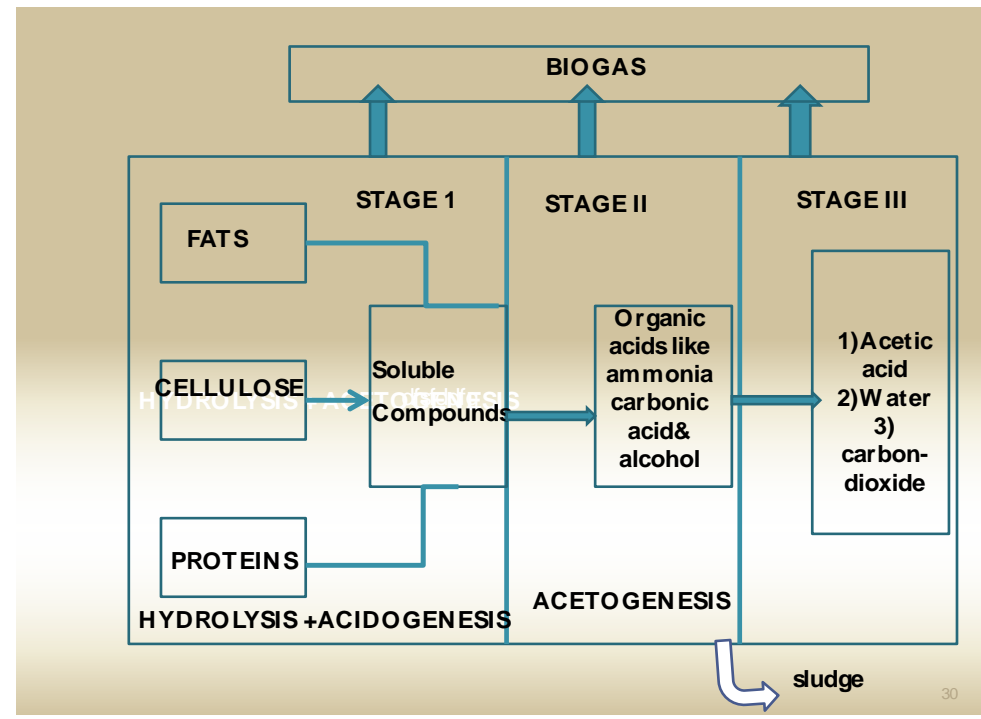

Fig 5:-Working procedure of HABR.

\section{F) Objectives:-}

The HABR has been described as a series of USABs which does not require granulation for its operation and it has lower start-up period than the other high rate reactors.Moreover, the HABR features in separating acidogenesis and methanogenesis longitudinally down the reactor and enhancing reactor stability. The main objectives is to examine the prompt start-up and the feasibility of HABR on treatment of molasses spentwash after modification, in terms of 
evaluation of removal of BOD,COD, variation of $\mathrm{pH}$, TFS,TVS and TFS and biomass analysis of anaerobic granular sludge.

\section{Functions:-}

- To separate and retain large amount of sludge in the reactor before the influent use the reactor.

- It was designed to increase the ability of entrapping microbe-rich small particles in the reactor.

- Proper effluent recycle was also applied to prompt the formation of granules. Effluent recycle might eliminate phase separation in traditional ABR, but when the height of HABR was increased, the problem may disappear and full phase separation is still to be discovered.

- The improved HABR was applied to treat wastewater after inoculated with commercial anaerobic granular sludge in this study.

\section{Experimental Investigations Of Molasses Spent Wash Before Treatment:-}

Physio-Chemical Characteristics Of Molasses Spent Wash:-

Table 1:- Physiochemical characteristics of molasses spentwash before treatment.

\begin{tabular}{|c|c|c|c|}
\hline S.No & Parameters & Raw Spent Wash & 20\% Diluted Spentwash \\
\hline 1 & Colour & Dark Brown & Light brown \\
\hline 2 & Odour & Unpleasant burnt sugar & Foul odour \\
\hline 3 & $\mathrm{Ph}$ & 5.5 & 7.27 \\
\hline 4 & Hardness & $7590 \mathrm{mg} / \mathrm{l}$ & $7400 \mathrm{mg} / \mathrm{l}$ \\
\hline 5 & BOD @3DAYS & $45540 \mathrm{mg} / \mathrm{l}$ & $32763 \mathrm{mg} / \mathrm{l}$ \\
\hline 6 & Chemical oxygen demand & $98760 \mathrm{mg} / \mathrm{l}$ & $75960 \mathrm{mg} / \mathrm{l}$ \\
\hline 7 & Total dried solids & $84500 \mathrm{mg} / \mathrm{l}$ & $74950 \mathrm{mg} / \mathrm{l}$ \\
\hline 8 & Total suspended solids & $45000 \mathrm{mg} / \mathrm{l}$ & $40000 \mathrm{mg} / \mathrm{l}$ \\
\hline 9 & Total volatile solids & $37940 \mathrm{mg} / \mathrm{l}$ & $35925 \mathrm{mg} / \mathrm{l}$ \\
\hline 10 & Total fixed solids & $100500 \mathrm{mg} / \mathrm{l}$ & $43000 \mathrm{mg} / \mathrm{l}$ \\
\hline 11 & Sulphate & $3000 \mathrm{mg} / \mathrm{l}$ & $60 \mathrm{mg} / \mathrm{l}$ \\
\hline 12 & Nitrogen & $1460 \mathrm{mg} / \mathrm{l}$ & $796 \mathrm{mg} / \mathrm{l}$ \\
\hline 13 & Potassium & $1430 \mathrm{mg} / \mathrm{l}$ & $856 \mathrm{mg} / 1$ \\
\hline 14 & Phosphorous & $326 \mathrm{mg} / \mathrm{l}$ & $150 \mathrm{mg} / 1$ \\
\hline
\end{tabular}

Over-Review From Before Treatment:-

From the above investigations carried out, it is clear that all the physio-chemical characteristics are above the disposal standards.

- The water is not suitable for disposal into land and water resources.So,the need for treatment of molasses spentwash is necessary for fruitful utilization of wastes.

- A closer examination of the constituents of the Molasses Spent wash, reveals that most of the constituents are carried from the Molasses.

- The excess calcium, phosphorous and sulfates are the result of clarification and sulfitation processes used in the sugar production.

- The rest of the elements come from the sugar cane.

- The spent wash is rich in Potassium, Nitrogen, and phosphorus and good for soil

\section{Results And Discussions:-}

After treatment using HABR,three major byproducts have been produced, they are as follows:

- Treated water

- Biogas

- Bio-manure(compost) 
The following byproducts are tested for physio-chemical characteristics. The characterization of byproducts helps in achieving the research objective.

Table 2:- Physio-chemical characteristics of treated water after treatment using HABR.

\begin{tabular}{|l|l|r|r|}
\hline S.NO & PARAMETERS & Values Of Treated Water & $\begin{array}{r}\text { CPCB Standards } \\
\text { For disposal }\end{array}$ \\
\cline { 1 - 2 } & Colour & Pale Yellow & Odourless \\
\hline 2 & Odour & Odourless & $6.5-9.0$ \\
\hline 3 & pH & Moderately soft & Soft \\
\hline 4 & Hardness & 86.9 & $100 \mathrm{mg} / 1$ \\
\hline 5 & BOD @3DAYS & 59 & $100 \mathrm{mg} / 1$ \\
\hline 6 & $\begin{array}{l}\text { Chemical oxygen demand(after } \\
\text { 7days treatment) }\end{array}$ & 89 & \multirow{2}{*}{$100 \mathrm{mg} / 1$} \\
\hline 7 & Total dried solids & 97 & \\
\hline 8 & Total suspended solids & 68 & 113 \\
\hline 9 & Total volatile solids & & \\
\hline 10 & Total fixed solids & & $36-72 \mathrm{ppm}$ \\
\hline 11 & Sulphate & & $10-20 \mathrm{ppm}$ \\
\hline 12 & Nitrogen & & \\
\hline 13 & Potassium & & \\
\hline 14 & Phosphorous & & \\
\hline
\end{tabular}

\section{Effect On Total Suspended Solids:-}

Total suspended solids are the dry weight of particles trapped by a filter. It is a water quality parameter used to assess the quality of wastewater after treatment plant. TSS was previously called non-filterable residue (NFR) but was changed to TSS because of ambiguity in other scientific disciplines.

Table 4.1 Effect of HRT on Total Suspended Solids

\begin{tabular}{|c|c|c|c|}
\hline S.No & $\begin{array}{c}\text { Hydraulic Retention } \\
\text { Time } \\
\text { Days }\end{array}$ & $\begin{array}{c}\text { Amount of TSS Present } \\
\text { In Sample } \\
\text { Mg/L }\end{array}$ & $\begin{array}{c}\text { \% TSS Removal } \\
\text { Efficiency }\end{array}$ \\
\hline 1 & Day 1 & 8950 & $75.96 \%$ \\
\hline 2 & Day 2 & 7340 & $81.62 \%$ \\
\hline 3 & Day 3 & 5320 & $92.28 \%$ \\
\hline 4 & Day 4 & 2790 & $94.7 \%$ \\
\hline 5 & Day 5 & 1430 & $95.10 \%$ \\
\hline 6 & Day 6 & 894 & $97.5 \%$ \\
\hline 7 & Day 7 & 325 & $98.2 \%$ \\
\hline 8 & Day 8 & 97 & $99.88 \%$ \\
\hline
\end{tabular}

From table 4.1,it is observed that the amount of totsl suspended solids gradually decreases as HRT increases.Also, maximum TSS removal efficiency was found at 8 days HRT for $0.5 \mathrm{~kg}$ OLR at reactor temperature of $35^{\circ} \mathrm{C}$.The garaphical representation of TSS removal efficiency for varying HRT is shown in fig 4.1. 


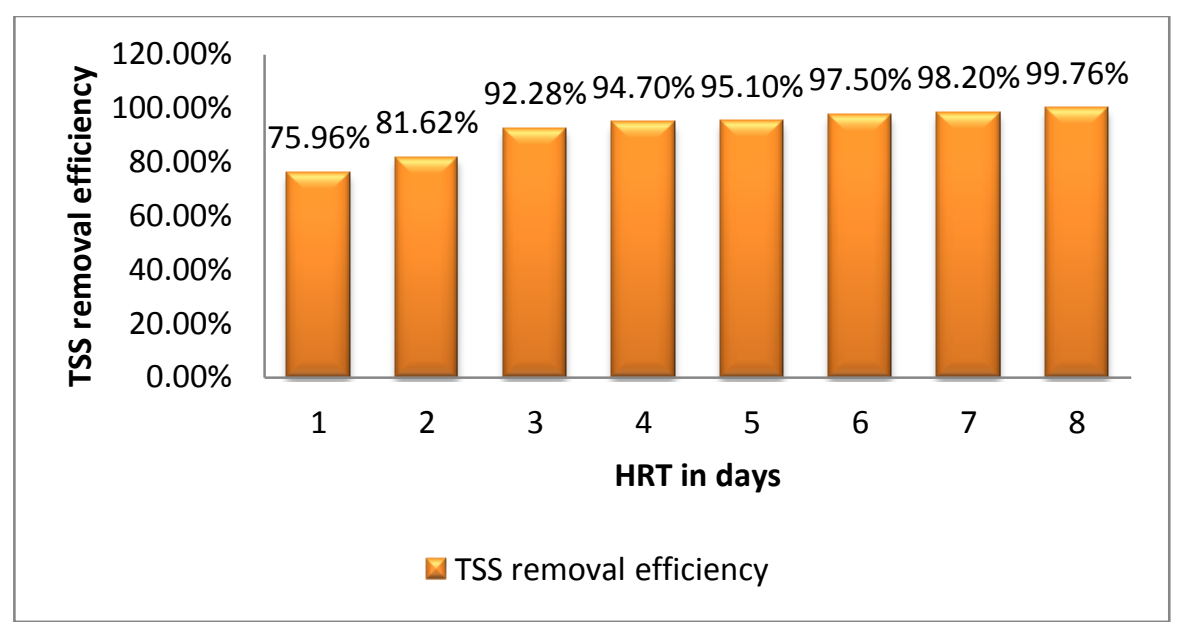

Fig 4.1 removal efficiency of TSS at $35^{\circ} \mathrm{C}$ for varying $\mathrm{HRT}$

Effect Of Total Fixed Solids \& Total Volatile Solids:-

From table 4.2,it is observed that the amount of total dried solids and total volatile solids gradually decreases as HRT increases.Also, maximum TDS\&TVS removal efficiency was found at 8 days HRT for $0.5 \mathrm{~kg}$ OLR at reactor temperature of $35^{\circ} \mathrm{C}$.The garaphical representation of TDS \&TVS removal efficiency for varying HRT is shown in fig 4.2

Table 4.2 Effect of HRT on Total Suspended Solids

\begin{tabular}{|l|c|c|c|c|c|}
\hline S.NO & $\begin{array}{c}\text { TIME PERIOD } \\
\text { Days }\end{array}$ & $\begin{array}{c}\text { AMOUNT OF TDS } \\
\text { PRESENT } \\
\text { mg/l }\end{array}$ & $\begin{array}{c}\text { \% tds } \\
\text { removal } \\
\text { efficiency }\end{array}$ & $\begin{array}{c}\text { AMOUNT } \\
\text { OF TVS } \\
\text { PRESENT } \\
\text { mg/l }\end{array}$ & $\begin{array}{c}\text { \%tvs removal } \\
\text { efficieny }\end{array}$ \\
\hline 1 & Day 1 & 7430 & $74 \%$ & 9211 & $75.96 \%$ \\
\hline 2 & Day 2 & 5321 & $79.2 \%$ & 7159 & $81.62 \%$ \\
\hline 3 & Day 3 & 2650 & $89.3 \%$ & 2920 & $92.28 \%$ \\
\hline 4 & Day 4 & 754 & $92.45 \%$ & 810 & $94.7 \%$ \\
\hline 5 & Day 5 & 532 & $96.43 \%$ & 595 & $95.10 \%$ \\
\hline 6 & Day 6 & 184 & $98.3 \%$ & 188 & $97.5 \%$ \\
\hline 7 & Day 7 & 123 & $98.91 \%$ & 125 & $98.2 \%$ \\
\hline 8 & Day 8 & 75 & $99.67 \%$ & 68 & $99.76 \%$ \\
\hline
\end{tabular}

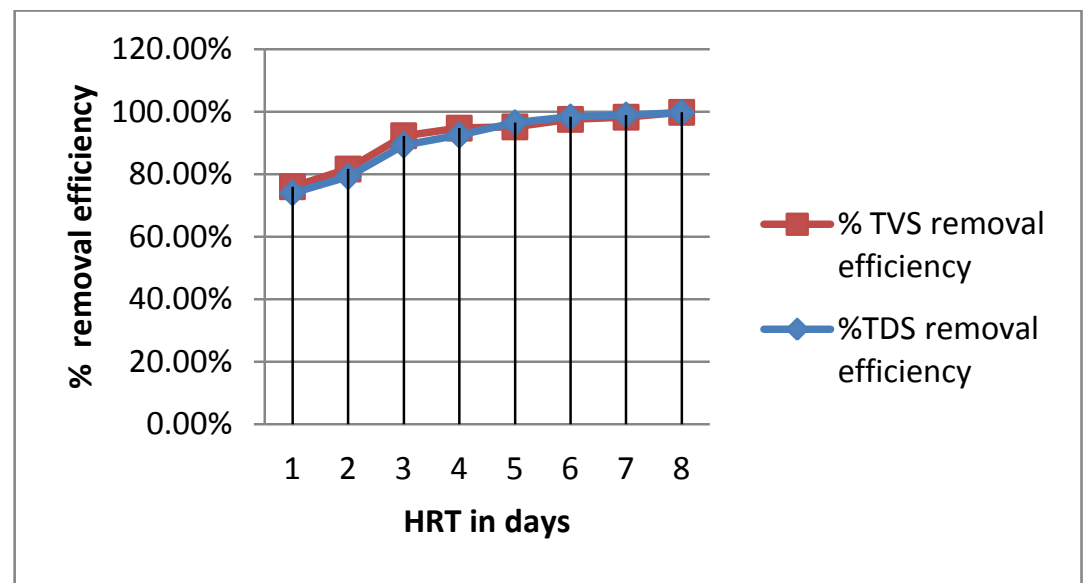

Fig 4.2:- \% reduction of TDS \& TVS with respect to time 


\section{Effect Of Bod:-}

BOD test is a wet oxidation process because the living organisms act as a medium for oxidation of organic matter to $\mathrm{CO}_{2}$ and water. Theoretically the biological oxidation takes long time but practically 20days may be sufficient.However, 20days period is too long to conduct, hence 5 days B.O.D in which 70 to $80 \%$ of the total BOD is come to the account, is calculated.It helps to determine the approximate quantity of oxygen that will be required to biologically stabilize the organic matter present, the strength of sewage and industrial effluents, measure the purification capacity of steams and so to design a treatment facilities accordingly and ascertain the efficiency of various treatment units. The test results in our sample shows drastic reduction of BOD as shown in fig 4.3 during the period of 8 days at a reactor temperature of $35^{\circ} \mathrm{C}$ FOR $0.5 \mathrm{~kg}$ OLR.

Table 4.3:- Reduction in BOD amount with respect to time period

\begin{tabular}{|c|c|c|c|}
\hline S.no & $\begin{array}{c}\text { Time period } \\
\text { Days }\end{array}$ & $\begin{array}{c}\text { Amount of bod present } \\
\text { Mg/l }\end{array}$ & Bod removal efficiency \\
\%
\end{tabular}

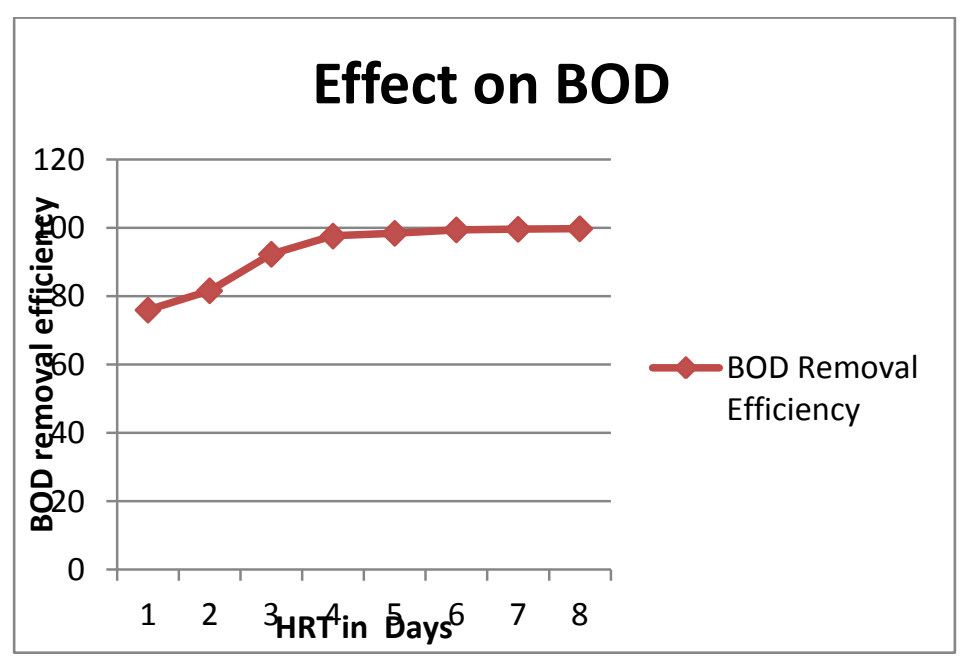

Fig $4.3 \%$ reduction of $\mathrm{BOD}$ with respect to time

\section{Effect Of Chemical Oxygen Demand:-}

Place $50 \mathrm{ml}$ of a sample diluted to $100 \mathrm{ml}$ in the refluxing flask (RBFlask). Add 1gm (half spatula) mercuric sulphate crystals to the sample.Carefully add $5 \mathrm{ml}$ sulphuric acid-silver sulphate reagent and dissolve the mercuric sulphate. Cool while mixing to avoid possible loss of volatile matter in the sample.Pipette out $25 \mathrm{ml}$ standard potassium dichromate solution into the RB flask and cool in an ice bath. While an cooling, add slowly 30ml of sulphuric acidsilver nitrate reagent very carefully and mix thoroughly.Remove the heating source, allow the flask to cool for half an hour and wash the condenser with distilled water in to the flask.Add 2-5drops of ferroin indicator and titrate with standard ferrous ammonium sulphate solution. The end-point is the sharp colour change from yellowish green to reddish brown through green and blue green.Conduct blank also using $100 \mathrm{ml}$ distilled water instead of sample. In our sample, a drastic reduction in COD content was observed during the period of 8 days @ $35^{\circ} \mathrm{C}$ for $0.5 \mathrm{~kg} \mathrm{OLR}$ which has resulted in subsequent production of biogas. 
Table 4.4:- Reduction in COD amount with respect to time period.

\begin{tabular}{|c|c|c|c|}
\hline S.NO & TIME PERIOD & $\begin{array}{c}\text { REDUCTION IN COD } \\
\mathbf{m g} / \mathbf{l}\end{array}$ & $\begin{array}{c}\text { COD REMOVAL EFFICIENCY } \\
\mathbf{\%}\end{array}$ \\
\hline 1 & Day 1 & $6583 \mathrm{mg} / \mathrm{l}$ & $91.33 \%$ \\
\hline 2 & Day 2 & $2001 \mathrm{mg} / \mathrm{l}$ & $97.36 \%$ \\
\hline 3 & Day 3 & $621 \mathrm{mg} / \mathrm{l}$ & $97.55 \%$ \\
\hline 4 & Day 4 & $103 \mathrm{mg} / \mathrm{l}$ & $98 \%$ \\
\hline 5 & Day 5 & $65 \mathrm{mg} / \mathrm{l}$ & $99.10 \%$ \\
\hline 6 & Day 6 & $60 \mathrm{mg} / \mathrm{l}$ & $99.5 \%$ \\
\hline 7 & Day 7 & $61 \mathrm{mg} / \mathrm{l}$ & $99.92 \%$ \\
\hline 8 & Day 8 & $59 \mathrm{mg} / \mathrm{l}$ & $99.95 \%$ \\
\hline
\end{tabular}

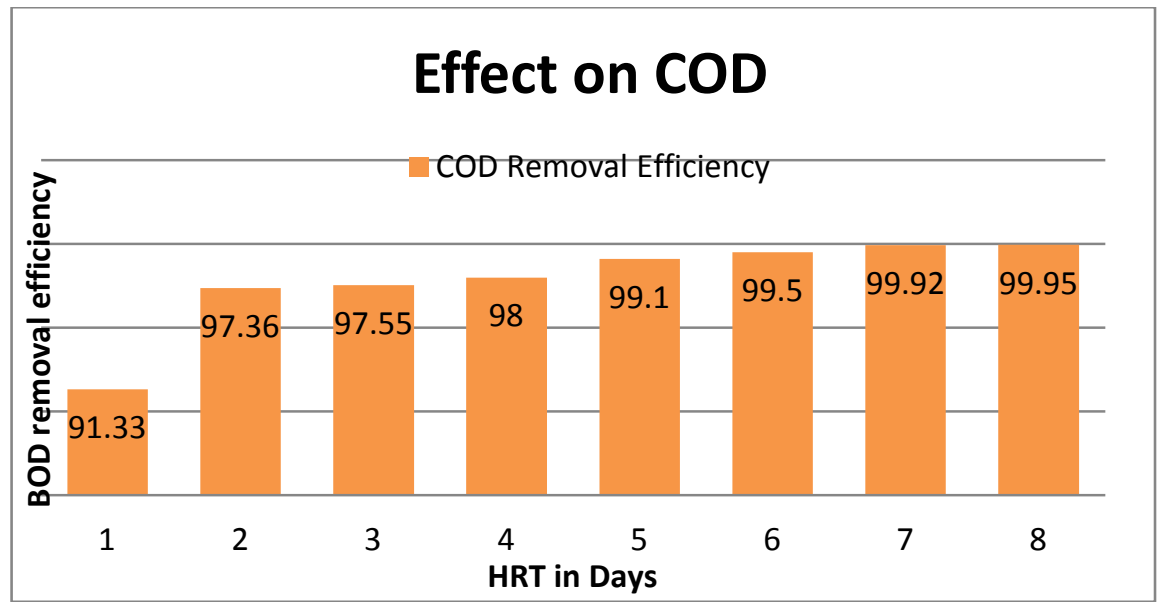

Fig 4.4\% removal of COD with respect to time

Comparison of Initial And Final Characteristics of MSW:-

It is found that the important waste water characteristics that cause environmental pollution has been decreased considerably after treatment using Hybrid Anaerobic Baffle Reactor and it is graphically represented as shown ijn fig 4.4.

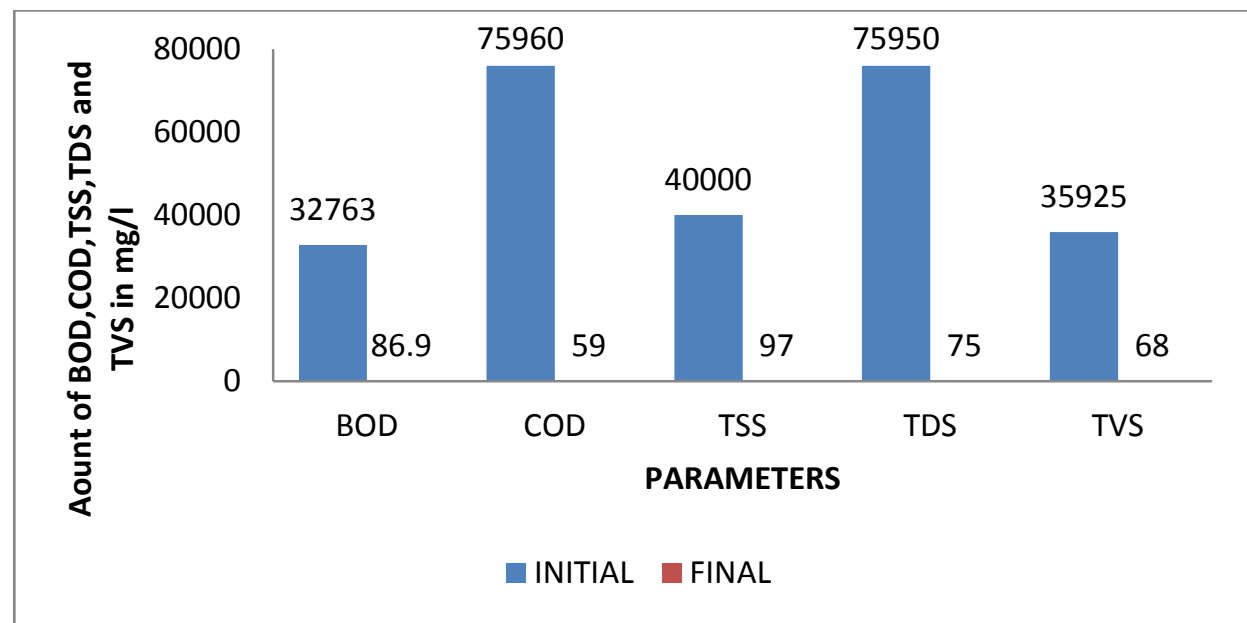

Fig 4.6 overall characteristics comparison chart for MSW 


\section{Chapter 5 \\ Conclusion:-}

Economy and technologies largely depend on energy resources that are not renewable. Also, the need for cost efficient and biological treatment technologies is of major concern .It is therefore necessary to identify and develop alternative sources of energy that are sustainable. The main objective to prove that Anaerobic treatment technology using Hybrid Anaerobic Baffle reactor coupled with Green Chemistry Approach and Zero Discharge Paradigm is the best solution in removing higher organic pollutant, low sludge production, biogas production,low energy consumption and in fruitful utilization of byproducts is achieved successfully. Significant amount of COD and BOD decreases with increase in time period at a temperature range of $35^{\circ} \mathrm{C}$ for $0.5 \mathrm{Kg} / \mathrm{m}^{3} / \mathrm{d}$. The results showed that removal efficiency for BOD, COD,TDS,TSS and TVS increased to $99.95 \%, 99.75 \%, 99.67 \%, 99.76 \%$ and $99.88 \%$ respectively.The biogas generation rate based on COD removed and presence of sulphate is $1.03 \mathrm{~m}^{3} / \mathrm{d}_{\text {and }} 0.97 \mathrm{~m}^{3} / \mathrm{d}$. The bio manure so produced from sludge remained during treatment is highly nutritive and the NPK values are within the standard limits that is useful for increased crop productivity.

It is recommended that adopting MEMBRANE TECHNOLOGIES along with Hybrid anaerobic Baffle Reactor helps in achieving 100\% utilization of Spent wash and maximum utilization of treated effluent for irrigation where bio-composting is not feasible must be an alternative option.

\section{References:-}

1. Noorahmed A. Hosmani1* And Amar S. Byakodi., (June-2016) ' Treatment Of Distillery Spentwash Using Downflow Stationary Fixed Film Reactor With Puf As Packing Material', International Journal Of Recent Scientific Research Research.,Vol. 7, Issue, 6, Pp. 11837-11840

2. Vandana Patyal.,(2015)Treatment of distillery waste water by anaerobic methods., International Journal of engineering research and applications., vol-5.,issue12(part3) ., pp:151-155

3. Lekshmi.S.R.,(2013).,Treatment and Reuse of Distillery Wastewater., International Journal Of Environmental Engineering and Management.,vol-4.,pp:339-344

4. A.S.Tanksali., (2013)., Treatment Of Sugar Industry Wastewater By Upflow Anaerobic Sludge Blanket Reactor ., International Journal of ChemTech Research.,Vol.5, No.3, pp 1246-1253

5. Pawar Avinash Shivajirao., (2012).,Treatment Of Distillery Wastewater Using Membrane Technologies, International Journal of Advanced Engineering Research and Studies Vol. I., Issue III., PP:275-283

6. P. Rath*, G. Pradhan, M.K. Mishra., (2010) .,Effect Of Sugar Factory Distillery Spent Wash On The Growth Pattern Of SugarcaneCrop., Journal Of Phytology., 2(5): 33-39

7. Gasparikova E., Kapusta S., Bodik I., Derko J., Kratochvil K. (2005). Evaluation of anaerobic-aerobic wastewater treatment plant operation. Polish Journal of Environmental Studies, 14, (1), 29-34.

8. Parawira W. (2004). Anaerobic treatment of agricultural residues and wastewater. Application of highratereactors, Doctoral Dissertation, Department of Biotechnology, Lund University, Sweden.

9. Nykova N., Muller T. G., Gyllenberg M., Timmer J. (2002). Quantitative analyses of anaerobic wastewater treatment processes: identifiability and parameter estimation. Biotechnology and Bioengineering, 78, (1), 89103.

10. Rumana R., Somchai D., Kannitha K. (2000). Anaerobic processes. Literature Review, Water Environment Research, 72, (5), 576-656. 